\title{
Analyzing Migration Management: On the Recruitment of Nurses to Germany
}

\author{
Jan Kordes ${ }^{1, * \mathbb{C} \text {, Robert Pütz }}{ }^{1}$ and Sigrid Rand ${ }^{1,2}$ \\ 1 Department of Human Geography, Goethe University, Theodor-W.-Adorno-Platz 6, \\ D-60629 Frankfurt am Main, Germany; puetz@em.uni-frankfurt.de (R.P.); s.rand@em.uni-frankfurt.de (S.R.) \\ 2 Institut für Wirtschaft, Arbeit und Kultur, Goethe University, Senckenberganlage 31, \\ D-60325 Frankfurt am Main, Germany \\ * Correspondence: kordes@geo.uni-frankfurt.de; Tel.: +49-69-798-35193
}

Received: 20 November 2019; Accepted: 14 February 2020; Published: 16 February 2020

\begin{abstract}
In Germany, a grave labor shortage in the nursing and elderly care sectors has prompted the response of recruiting skilled nursing staff from abroad in recent years. This article analyzes these recruitment practices as forms of "migration management": German migration policy has changed according to this paradigm to attempt utilitarian control over migration processes and mediate between labor market concerns on the one hand and isolationist, politico-cultural seclusion on the other. Based on original research through interviews and document analysis, we identify four relevant levels of analysis in researching migration management in the context of the recruitment of skilled nurses: (1) Definition of problem areas: How is migration programmatically legitimized as a solution to social problems? (2) Categorization of migration: How are migration processes classified? (3) Change in statehood: How are sites and actors of migration control being privatized and diversified? (4) Technologies: By means of which procedures, legal foundations and political instruments does migration management take place in the everyday? We believe that taking these four foci as points of departure would be beneficial for further inquiries in critical migration research.
\end{abstract}

Keywords: care; migration; migration management; nursing; recruitment; globalized labor markets; Germany

\section{Introduction}

For some years now, it has been maintained that Germany's health and care sector is suffering from a serious shortage of skilled care personnel, which is expected to become even more severe in the future (Hämel and Schaeffer 2013, p. 423). Forecasts predict a lack of up to 520,000 full-time nurses in 2030 (Prognos 2012, p. 2). ${ }^{1}$ The reason given for this is usually a growing demand for care in the wake of demographic change, along with a concurrent shortfall in the supply of nurses. Today, hospitals, nursing homes, and home care providers are already experiencing great difficulty replacing skilled personnel upon retirement or otherwise leaving the industry. The causes for this lie in the economization of the health and care sector: the changes in the structure of funding and of incentives have led to higher demands on productivity, while the patient-staff ratio has remained the same or even declined, resulting in nurses having to shoulder a both mentally and physically more exhausting workload. As a consequence, in 2017, an opening for a hospital nursing position remained vacant for

1 While Germany is also a destination country for (informal) carers providing long-term care in private homes, this article focuses on qualified nursing professionals working in hospitals, elderly care homes and for mobile health care providers. 
an average of 146 days and in elderly care for 171 days (Bundesagentur für Arbeit 2018a, pp. 12-13), while the average of all openings was only 103 days (Bundesagentur für Arbeit 2018b, p. 6).

Against this backdrop, recruiting nurses from abroad has become a key strategy in maintaining a sufficient workforce in the health and care sector in Germany (Braeseke et al. 2013; Bonin et al. 2015; Bundesministerium für Familie, Senioren, Frauen und Jugend 2012; Bundesministerium für Wirtschaft 2012). Members of the German federal government have explicitly suggested pursuing a large-scale foreign recruitment policy (Federal Minister of Health Jens Spahn) and advocated for specific exemption clauses in right-of-residence law (Federal Minister of Labor Hubertus Heil) (Bild am Sonntag 2018) or proposed special provisions for refugees in the care sector (Neues Deutschland 2018).

We will argue that, in Germany, immigration policy is increasingly being framed in terms of its labor market potential or, more broadly, as a solution to various societal problems. The changing expectations toward migration not only create a basis for classifying migratory movements as desirable or detrimental, but also divert attention from complex drivers of migration and the subsequent inclusion of migrants into German society. Therefore, it is important to explore how and to what extent the principles of migration management are shaping migration processes in Germany. Referring to existing literature and based on our own research, we identify four constitutive elements of migration management: (1) presenting migration as a solution strategy for different problem areas in the society; (2) defining supposedly distinct categories of migrants that are used to facilitate or hinder their access to the host society; (3) involving new (types of) actors in policy-making and implementation; and (4) devising technologies (e.g., programs and procedures) that support the steering of desirable migration.

As the care sector is already largely regulated in accordance with labor market demands, it is particularly suited for tracing how the shift toward a potential-oriented migration policy is actually taking place. Our own research on the recruitment of nurses ${ }^{2}$ demonstrated how different kinds of actors identified potential pools of skilled nurses in other countries, eliminated barriers and defined immigration paths for potential workers on the basis of utilitarian criteria, thus testing their ability to persevere in the labor market. Moreover, it was often argued that utilitarian principles should be applied to programs designed to admit immigrants on humanitarian grounds. This article will discuss the research results along the four proposed dimensions we identified as guiding principles for managed migration. As these developments can also be expected to extend to other "shortage occupations" in the future, the analytical framework can be developed further to reflect the application of the principles of migration management to other fields of migration or types of migration. In our view, the framework presented here makes the recent shifts in migration policy toward a utilitarian rationality visible. Thus, it enables a comprehensive critique of the attempts to capitalize on the divisions and stratifications within the myriad of migration phenomena.

\section{The Principles and Politics of Migration Management}

The concept of migration management suggests that if migration processes are managed in a strategic manner, it benefits all parties involved. Thus, the advocates of this approach claim to be able to mediate between economic needs and politico-cultural attempts at isolation by introducing principles of utilitarian optimization to the steering of migration processes (de Jong et al. 2017, p. 4).

2 The empirical research referenced in this paper took place between 2015 and 2017 during the project Betriebliche Integration von Pflegefachkräften aus dem Ausland (Organizational integration of foreign nurses) conducted by the Department of Human Geography, the Institut für Wirtschaft, Arbeit und Kultur (Institute for Economy, Labor, and Culture) and the Institut für Sozialforschung (Institute of Social Research) [all at Goethe University, Frankfurt am Main] and funded by the Hans Böckler Foundation. During this endeavor, which is only partially referenced here, 14 interviews with representatives of employers, recruitment agencies, vocational training institutes and qualification recognition authorities (among others), as well as 40 narrative interviews with migrant and autochthon nurses, were conducted. While we consider the perspectives of migrant nurses themselves to be essential, their voices and experiences are not part of this paper due to the focus on a specific political project of migration management. Their perspectives were reflected at length in other publications resulting from the project, which were published by Pütz et al. (2019). 
However, rather than pursuing an overarching strategy, such endeavors remain heterogeneous and involve state institutions, supranational organizations, and think tanks, as well as private enterprises. These new types of actor constellations, as well as the increasing role of private actors in developing and implementing sector-specific instruments as technologies for steering migration, reflect new relations of power in society and a fundamental change in statehood (Buckel 2012; Forschungsgruppe »Staatsprojekt Europa« 2014).

In Germany, a long phase of attempted isolation against immigration in the course of the recruitment ban in the 1970s has been superseded by a paradigm focused on the potential of immigration (Pütz and Rodatz 2013), which has found expression in new types of migration management. What this refers to is a policy approach that also perceives migration as a resource and is explicitly guided by the "economic and labor market policy interests of the Federal Republic of Germany" (§ 1, German Residence Act).

At the European level, the European Commission together with think tanks such as the International Centre for Migration Policy Development and the International Organization for Migration have been driving forces for a greater openness toward a migration management policy guided by a focus on human capital (Parusel 2010; Georgi et al. 2014). The main instrument regarding labor market entry in EU-migration policy has been the Blue Card directive, which has, however, ultimately had only scant effect in terms of steering migration (Georgi et al. 2014, p. 210). The European level nevertheless continues to play an important role in the analysis of migration management because it has placed migration more prominently on the agenda of the EU Member States and issued other legal regulations (see Section 3.4). However, compared with other countries, Germany was late in initiating the shift toward a migration management driven by labor market demands (Kannankulam 2014). The change began in 2000 with a green card initiative for IT professionals and continued with a reform of citizenship law and the introduction of the Immigration Act in 2005. The federal government saw the Immigration Act in particular as an important component for steering immigration according to economic needs and opened up additional avenues for immigration primarily for highly qualified individuals from third countries (Ette et al. 2012, p. 16). Between 2011 and 2013, the paradigm shift in immigration policy for the highly qualified gained increasing momentum in the wake of reforms such as the comprehensive implementation of the Blue Card directive in Germany or the introduction of $\S 6$, para. 2 of the Employment Regulation (Kolb 2014, p. 73), which led the Organization for Economic Cooperation and Development to state, as early as 2013, that Germany displayed a rather liberal system of immigration for the highly qualified (Kolb 2014, p. 71).

The political project of recruiting nurses to Germany refers back to several of these policy changes, but was also made possible through changing cultural framings of migration. Meanwhile, the migration of nursing professionals has become the prime example of migration management in Germany. After laying out the context in which this development took place, we will now demonstrate how these migratory movements are shaped by the techniques of migration management along the four dimensions identified through our research.

\section{Analyzing Migration Management: Recruitment of Nurses in Germany}

\subsection{The Demographization of the Care Crisis: Migration as a Solution Strategy}

A constitutive feature of migration management is a programmatic legitimation suggesting that key social problems can be solved by means of (orderly) migration. In this vein, the term migration management refers to the supposed ability to pursue a rationally motivated migration policy on the basis of expert knowledge (Geiger and Pécoud 2010, p. 11; Georgi 2007, pp. 72-73). In the context of migration, this notion can be pitted against deep-seated resentment associated with migration (Balibar 2005).

The skill shortage in the health and care sector is a much-discussed problem. Estimates of the expected shortfall in care staff range from about 55,000 (in 2025; Afentakis and Maier 2010) to 520,000 
(Prognos 2012, Prognos 2012) full-time jobs (Rothgang et al. 2012; Ehrentraut et al. 2017). The wide discrepancy between these figures is in itself a clear indication that a skill shortage is not an objective state of affairs. Defining it is already part of the scientific-political construction of such a shortage, which in the current debate is characterized by abstracting from the deeper politico-economic and cultural issues of an insufficient funding and devaluation of care work. For instance, an aspect that remains underexposed is that the economization of the health system has resulted in changes in the structure of funding and of incentives as well as in a successive deterioration of working conditions in the health and care sector (Chorus 2013; Winker 2015, pp. 75-77; Auth 2017, pp. 313-15). Cost-reduction strategies have increased productivity through the intensification of work, low wages, and cutbacks in patient-staff ratios (Hedemann et al. 2017). However, the current debate on an aging society and a lack of skilled workers tends to hide these relations from view. To reflect on this theoretically, we could draw on a term coined by Schultz (2016, p. 120) and speak of a "demographization" of social problems. What this term seeks to express is that a skill shortage, for instance, is constructed as a demographic problem and negotiated in terms of the number of qualified workers while losing sight of issues of employment relationships and working conditions (Schultz 2016, pp. 121-25).

Instead of addressing the latter, strategies of securing a qualified workforce call for recruiting nurses from abroad and thus suggest that it is basically possible to deal with the care crisis via migration (Kordes 2019). This approach legitimizes migration as being essential for a changing society to fill the gaps of the demographic pyramid or in specific segments of the labor market (Meissner 2018, p. 294). The diagnosed care crisis is a focal point where these two gaps overlap. The Federal Ministry for Family Affairs, Senior Citizens, Women and Youth's "Elderly Care Education and Training Initiative (Ausbildungs und Qualifizierungsoffensive Altenpflege)" repeatedly refers to the seemingly inevitable demographic constraints and then draws the following conclusion:

"The partners agree that, because of the substantial increase in the demand for skilled personnel in elderly care, not only must the domestic [sic] potential be more strongly promoted and tapped to secure a foundation of skilled staff, but the potential available in the EU labor market, as well as, at least in the mid to long term, qualified immigration from third countries, must also be fully utilized" (Bundesministerium für Familie, Senioren, Frauen und Jugend 2012, p. 48). ${ }^{3}$

But what impact has this strategy already had on the labor market in the care sector? Since 2012, several recruitment programs along with exemption clauses in immigration law have boosted the migration of nurses to Germany considerably. ${ }^{4}$ As a large part of those migrants come from EU countries and therefore enjoy freedom of movement, this increase in the immigration of nurses can be determined only by consulting statistics on the recognition of credentials. ${ }^{5}$ According to these statistics, the number of annual applications for the recognition of credentials in the care sector has increased from approximately 1.500 in 2012 to around 11.500 in 2018 (cf. Figure 1). Until 2014, this increase originated primarily from other EU countries; since then, however, requests for recognition from third countries have surpassed it, signaling the influence of current migration management practices on migration channels and patterns.

3 All quotes were translated from German by the authors.

4 Statistically, it is not possible to differentiate between autonomous and recruited migration. Although autonomous migration originates primarily in countries that enjoy privileges arising from freedom of movement, these countries are also subject to private and public recruitment initiatives. Conversely, it is possible to immigrate from third countries in the absence of recruitment activities. However, this involves considerable effort. All statistical data regarding recognition proceedings refer to the country of issuance of the respective diploma, not the citizenship of the applicant-although the two are almost exclusively identical.

5 As a result of this lack of statistical data, the actual number of migrants seeking employment as nurses is larger than indicated here but cannot be determined precisely. Conversely, it is conceivable - although presumably only in individual cases - that people whose credentials have been recognized upon applying from their home countries may ultimately abstain from migrating to Germany (Schmitz and Winnige 2019, p. 8). 


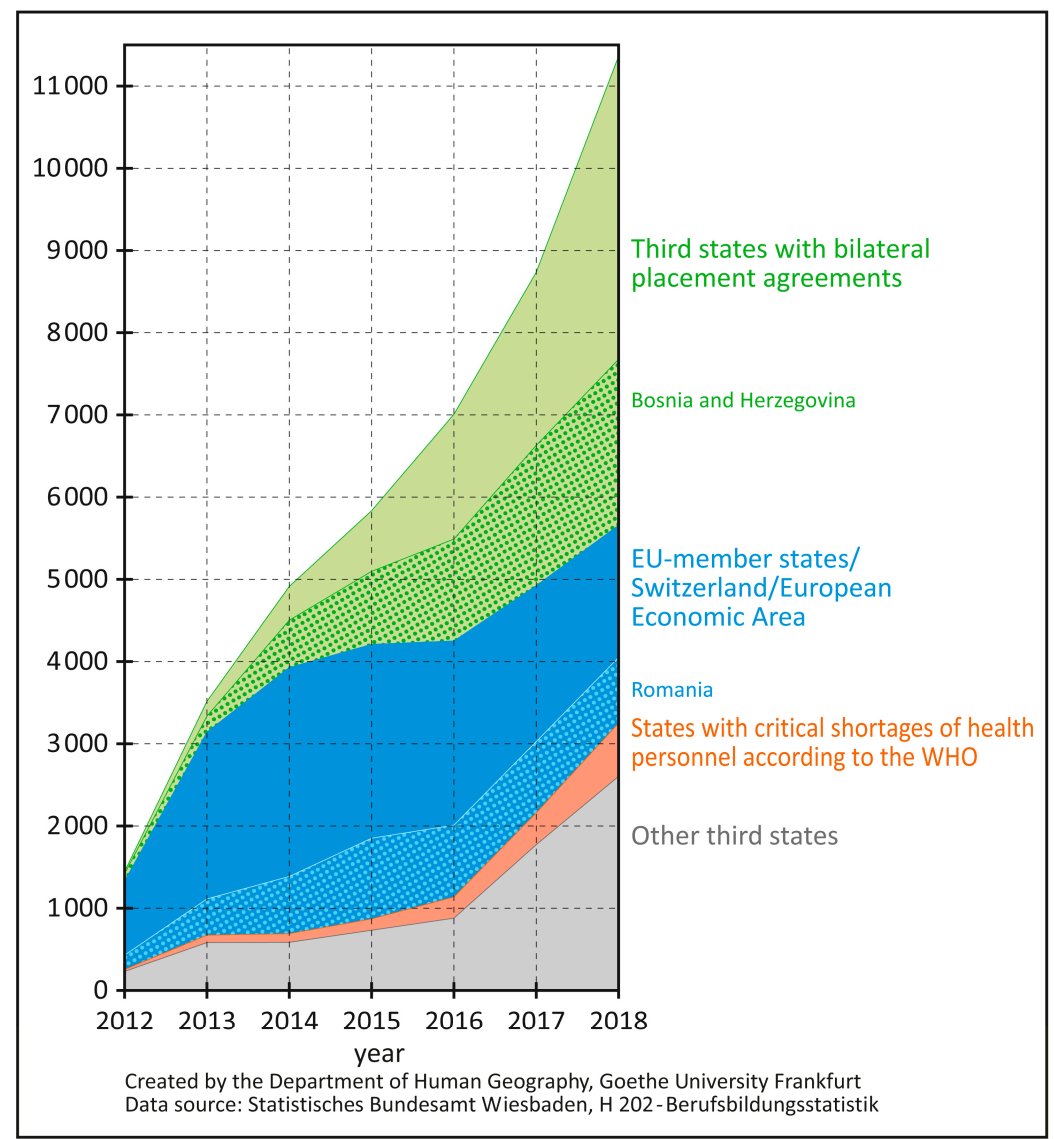

Figure 1. Number of new applications per year for recognition of credentials as registered nurse by region and selected states, 2012-2018.

A large part of this immigration is an immediate result of a change in the management of migration in the care sector, namely the introduction of public programs, launched in 2013 at the latest, to recruit individuals from this occupational group. These programs, such as MobiPro-EU, for instance, targeted other EU countries. It was one of the public programs that paved the way for the concerted recruitment of nurses from abroad. It addressed individuals between 18 and 35 years of age who were registered as unemployed in an EU member state and willing to take up skilled employment in a "shortage occupation". It was open not only to state but also to private sector agencies, and was thus a typical example of the increasing significance of private actors in managing migration processes. MobiPro-EU covered expenses for language classes, relocation, and recognition procedures on behalf of participants and agencies (Bundesministerium für Arbeit und Soziales 2016).

Other programs were launched specifically for the recruitment of nurses from third countries. The most important one since 2013 is Triple Win, which was initiated by the GIZ (Gesellschaft für Internationale Zusammenarbeit, the quasi-public German agency for development cooperation) in conjunction with Germany's Federal Employment Agency. Triple Win involves bilateral placement agreements with four third countries (the Philippines, Bosnia-Herzegovina, Serbia, and Tunisia). Moreover, the same players launched a recruitment program with Vietnam in 2013 to guide certified nurses into vocational training for elderly care. The tremendous significance of these recruitment programs for recruiting candidates from third countries is reflected in the application numbers (cf. Figure 1): the few countries involved in these recruitment programs account for almost the entire increase in applications from third countries, in comparison to about 100 other third countries responsible for the remaining small numbers.

Furthermore, the analysis of the available data shows that Germany has gained increasing significance as a destination of global labor migration, which it is seeking to consolidate. Upon 
request from the Free Democratic Party (FDP), the federal government recently gave a comprehensive account of its plans to further expand recruitment activities (Bundesregierung der Bundesrepublik Deutschland 2018). The FDP's care policy spokesperson, Nicole Westig, remarked in response that the results are still insufficient. She stated that, in light of the dramatic situation in the labor market for nurses, all potentials must be utilized and that recruitment could be an important component to do so (Szent-Ivanyi 2018). This illustrates that migration policy is perceived to be a legitimate solution strategy to address the care crisis. The relevance of this strategy is reflected not only in sheer numbers but also in current efforts to develop new structures that would position Germany as a destination for nurses from abroad.

\subsection{Categorization: Figures of Migration in the Care Sector}

To utilize the aforementioned migration potentials, it is a constitutive practice for migration management to categorize migration flows and the migrants involved. Such processes of sorting are central to the functioning of migration management as they determine which types of migration (e.g., countries of origin and paths of migration) and which migrants (e.g., characteristics of their work history and other attributes) are to be encouraged and which ones are to be preferably stopped. In principle, migration management distinguishes binarily between desirable and undesirable forms of migration (de Jong et al. 2017, p. 4). From a governmentality perspective, Ratfisch (2015) has termed such programmatic distinctions as idealized "subject figures of migration (Subjektfiguren der Migration, our translation)". He understands the EU's categories of legal, illegal, ${ }^{6}$ and humanitarian migration as an attempted ordering of diffuse migration phenomena. The "rationalisation" (Lagios et al. 2018, p. 9) of migration control is conditional on the discursive production of such orderings.

According to this categorization, foreign-trained nurses are essentially defined as "desirable" migrants. Our analysis shows that, beyond this basic classification, there exists a fine-grained system for categorizing migrated nurses that depends on their certified skills and the degree to which these can be economically utilized in the labor market. According to our research, these more detailed categorizations are applied primarily by labor market intermediaries involved in the placement of nurses (see our discussion of actor constellations and technologies in Sections 3.3 and 3.4). As "marketizing agencies" (Çalışkan and Callon 2010, p. 8), these intermediaries play a crucial role in shaping migrants into tradable commodities and determining their market value and thus contribute to establishing and stabilizing the market for nurse placements. In this context, marketization means that nurses are prepared-in spatially and temporally differentiated processes ranging from training in their countries of origin to employment in a German care facility-in line with the demands of (potential) employers so that they can be placed as workers in the labor market. In this way, migrants are objectified as nurses, which involves differentiated processes of stratification and categorization Rand et al. 2019, pp. 49-51).

One of the key characteristics for distinguishing the commodity of "nurse" proves to be the certified level of proficiency in German. In the recruitment process, level B1 or B2 is the minimum for recognition of credentials. From the perspective of agencies and employers, language proficiency beyond these levels not only enhances their "market value" considerably but also serves as an indicator of greater extralinguistic skills. Our study shows that supposed language deficiencies are taken as a sign of a lower capability or limited occupational aptitude of the nursing recruits:

“We begin with simple personal care and making beds; the very easy stuff. When that's covered, they have to document it. Because this is also an important part of the tools of the trade. Then we wait and see what their German is like, as it were" (Practical instructor/mentor (Ward A), Hospital 1)

6 Ratfisch deliberately employs the language used by the European Council. We prefer speaking of 'illegalized migration' (Düvell 2002, pp. 52-53) to indicate that humans as such cannot be illegal; only by means of legal intervention is the mode of 'illegality' constructed. 
Objectification also takes place by separating nurses from their social relationships in their countries of origin and tying them to labor market intermediaries or would-be employers. Both moves enhance the calculability of the placement process and reduce the costs involved, respectively:

"Because the young ones (nurses from Romania) often already have children and a family. (laughing) (...) Yes, they typically stay at home. (...) It's clear; the two months here are without children. And that has to be clear from the outset because they cannot learn as much if a child is here." (Placement officer 3, Hesse)

Our interviews show that the image that employers and placement agents have of the future nurses reflects a specific subjectivity (Rand et al. 2019, pp. 51-53), or what Ratfisch calls a discursive "figure of migration" (Ratfisch 2015, p. 3). In our interviews, five sought-after attributes correspond to this image of desired nurses: malleability, willingness to adapt, high motivation, flexibility of commitment, and high geographical mobility. Migrants are therefore constructed as working subjects with useful skills and individual abilities who must be provided conditions to enable channeling their actions and labor power into desired paths (Ratfisch 2015, p. 10). Our interviews indicate that the nurses are judged by the extent to which they have internalized those principles of economic rationality (Tomei 2016), and thus already conform to the type of subject associated therewith:

"There is this example - the question at the core of emotional intelligence - you are probably familiar with it: 'A lollipop now or two lollipops an hour later.' (... ) And ultimately we want two lollipops; we offer two lollipops, but you have to wait six month before you get the lollipops; and this question is of a selective nature. Because there are people who cannot imagine this in the first place; they can't think about such cycles; they don't want to. Those are therefore not the right ones. And those who don't want to do this won't learn the language either. (...) We still explain it, but we also let it stand as a selective criterion. Because the person who is willing to muster emotional intelligence to this degree and say 'I know it's worth the investment' is also a reliable worker in the long run." (Placement officer 1, Hesse)

Migration management that increasingly includes private actors in the process of steering migration turns migrants into the commodity of "labor power", which goes hand in hand with multifarious categorizations in regard to their "market value". Here, categorizations of a more individual kind overlap with structural aspects such as geographic origin (cf. Figure 2). Accordingly, we find a multitude of divisions and classifications of migrants within a category such as "legal migration". This differentiation of access paths and rights might be referred to as a "politics of categorization (Mourão Permoser 2017, p. 2550) and is highly significant for those affected as it creates stratified access and multiple legal positions. In the nursing field, distinctions are made according to four regions: (1) EU member states, ${ }^{7}$ with freedom of movement and harmonized recognition of credentials; (2) third countries that enjoy preferential treatment and are targeted by recruitment programs; (3) other third countries; and (4) countries in which the World Health Organization (WHO) has determined a critical shortage of health personnel and should therefore not be subject to such recruitment (WHO 2006, p. 12). ${ }^{8}$

7 Liechtenstein, Norway, Iceland, and Switzerland are essentially treated on the same terms as EU member states.

8 The WHO list has been adopted into German law so that, according to $\S 38$ of the Employment Regulation, the German Federal Employment Agency is the only eligible placement service provider for individuals from the 57 countries on that list. 


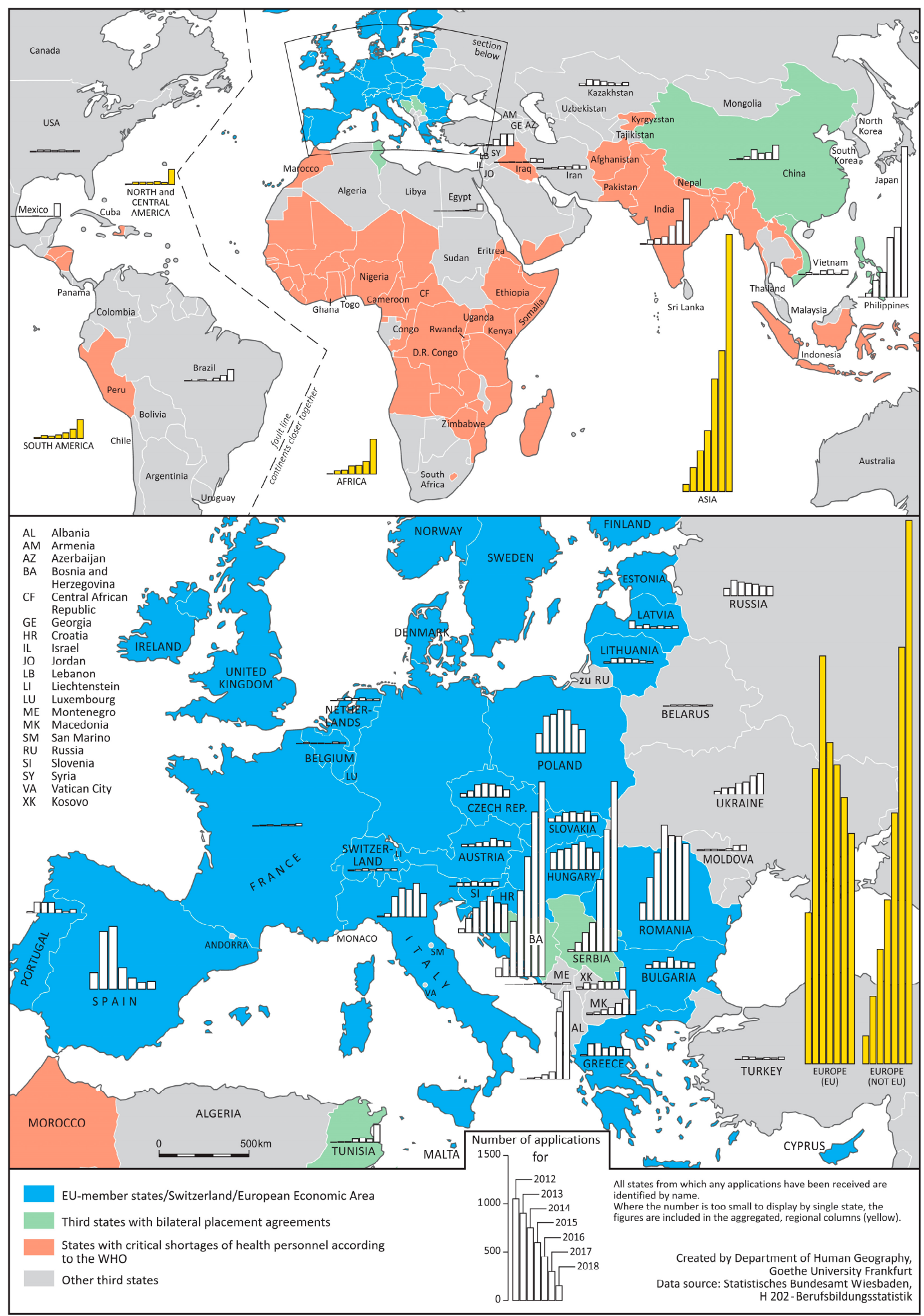

Figure 2. World map displaying the number of new applications for recognition of credentials as registered nurse by distinct regions of origin, as well as individual countries, 2012-2018.

\subsection{Change in Statehood: Privatization and Diversification of Migration Control in the Case of Nurses}

Migration management is invariably associated with a change in statehood that is reflected in newly assembled and weighted actor constellations involved in initiating and implementing the respective policies. Accordingly, we have been witnessing a shift in the functions of migration control 
in recent years that is transforming the role of the state (Menz 2011). The state is increasingly assuming the role of a manager and is assigning key tasks of implementation to private actors (e.g., private recruitment agencies) in a multi-scalar actor network (Hess et al. 2014, p. 15). Scott (2017, p. 396) describes this process as "rescaling and venue expansion". According to this reasoning, there have been "outward, upward and downward" shifts in initiating, implementing, and accounting for migration policy. An outward shift can involve, for instance, the externalization of risk or the engagement of external expertise, or an upward shift, for example, the regulation of labor migration at the European level (Scott 2017, pp. 397-98).

The recruitment of nurses takes place in such a diverse network of state and non-state actors that spans across multiple scales. This can be traced particularly well with regard to an initiative created by the state of Hesse: as early as 2012, the Hessian state government launched an initiative for the recruitment of young, unemployed nurses from the Community of Madrid for Hesse's elderly care facilities (Rand et al. 2019, p. 43). The pilot project was developed in cooperation with the Federal Employment Agency's Regional Directorate Hesse (Regionaldirektion Hessen der Bundesagentur für Arbeit), the League of Non-Statutory Welfare Services in Hesse (Liga der Freien Wohlfahrtspflege in Hessen), and the Federal Association of Private Social Service Providers (Bundesverband privater Anbieter sozialer Dienste) (Hessisches Sozialministerium 2013). The Federal Office for Migration and Refugees (Bundesamt für Migration und Flüchtlinge) covered the costs of language courses, and MobiPro-EU subsidized nurses' relocation expenses. The recruitment initiative coordinated the activities of the participating actors. It collected information on the labor needs of elderly-care facilities in Hesse and accompanied representatives of these facilities to a job fair in Madrid. Additionally, a B1 level language course specifically tailored to the needs of the care sector was developed in collaboration with the Darmstadt regional administrative authority, which is in charge of recognizing qualifications acquired abroad, and StartHaus Offenbach, which is a non-statutory youth welfare service provider.

In the countries of origin, where mobilization, selection, and initial preparation of would-be migrants takes place, networks of actors form as well. Their primary role is not in the field of job placement in the narrow sense but in laying the groundwork for migration (Rand et al. 2019, pp. 48-49). For instance, universities are encouraged to prepare nurses for the possibility of migrating at a later point in time (e.g., "by replacing English with German in classes teaching foreign languages, with the prospect of being prepared for migration"; Placement officer 1, Hesse). Language schools in the countries of origin are involved in the recruitment activities by participating in the process of selecting the nurses or assisting in the conclusion of contracts. These language teachers also act as "culture brokers" (Moroşanu 2016, pp. 359-61; Bludau 2015, p. 96) in that they advise the nurses during language classes regarding how to behave in workplace and everyday settings in Germany. At the same time, they assume the task on behalf of labor market intermediaries of monitoring the participants' learning success and their performance potential.

A key aspect of current recruitment initiatives is the involvement of labor market intermediaries, among them temporary employment and job placement agencies (Rand et al. 2019, pp. 43-45). In recent years, they have discovered the recruitment of nurses from abroad as a new, promising line of business and have developed their service portfolio accordingly. This has been further enhanced by the fact that, after some initial attempts, many employers abandoned their own recruitment activities in favor of outsourcing them to private sector or state-like actors (e.g., GIZ). In other cases, care facilities developed the recruitment of skilled staff into a business model of their own, mixing the role of service provider and labor market intermediary:

"First, for our own needs. Then we became aware of how much work it actually involves and how much energy it consumes. And then we said, 'Okay, plenty of others have the same problem that we have.' And then we turned it into a business model." (Director of an elderly-care facility, Hesse) 
As Benner (2003, p. 622) has shown, labor market intermediaries can establish themselves as actors because they reduce employers' transaction costs of recruitment from abroad, manage the risks involved in the recruitment process, and develop networks to support recruitment activities. In line with this finding, we can state for the German labor market in the field of nursing that labor market intermediaries ensure the continuous adaptation of regional labor markets to changing circumstances. As our project shows, intermediaries promise a reduction in the high transaction costs arising from non-transparent circumstances surrounding the recruitment process - both for employers and for the nurses (Schwiter et al. (2014) have observed similar behavior for placement agencies in private home care settings).

To a large extent, the aforementioned groups of private sector actors rely on state initiatives to open up the field of recruitment strategically. In this process, the role of the state is not limited to creating a regulatory framework but also involves deliberate measures to prepare and support specific recruitment channels. Such state-driven recruitment initiatives intend to establish Germany as an attractive destination country in globalized labor markets for nurses. State authorities provide the following services in the context of recruitment initiatives:

- Matching demand for skilled labor in Germany with the supply of skilled labor in EU countries in accordance with the principle of the free movement of labor within the EU (e.g., the Federal Employment Agency's Foreign Placement Agency (Zentrale Auslands und Fachvermittlung), together with European Employment Services, organizes job fairs in other EU countries);

- $\quad$ Providing a systematic overview of the formal and organizational aspects involved in recruitment from third countries, which employers frequently perceive as representing substantial barriers, and making it available to a variety of actors (e.g., checklists for recruitment, language and skill-oriented preparation in the country of origin, application of residential and working permits in Germany; (Peters et al. 2016);

- Creating platforms for projects where common agreements can be made that extend to all participating organizations (e.g., in the context of the Hessian recruitment initiative, an agreement was reached defining the conditions under which recruits could continue attending language classes during their induction phase).

Despite the long-term prospect, establishing the recruitment of nurses as a strategy for securing skilled personnel in the care sector is regarded as being of a temporary nature. In addition, the participation of public authorities in the Hessian project was not intended to be a permanent arrangement as in other pilot projects. The goal was for market actors to secure their supply of skilled labor on their own:

"We only make the offer; as an association, we're only attempting to organize it as a service, so that the companies can do it. But how they do it in the end is simply up to them."

(Representative of an association of service providers, Hesse)

\subsection{Technologies: Steering the Migration of Foreign-Trained Nurses}

An essential element in the functionality and stabilization of new forms of managing migration is devising specific technologies for steering migration in politically desirable ways. In line with Rose and Miller, what we have in mind here are those "programmes, calculations, techniques, apparatuses, documents and procedures through which authorities seek to embody and give effect to governmental ambitions" (Rose and Miller 1992, p. 175). As socio-technical processes, technologies for steering migration are a manifestation of a biopolitics that aims to influence the composition of the population (Georgi 2007, p. 64). Moreover, such technologies obscure the political background of migration management by directing attention to management tools and issues of technical viability. Steering through technology engenders a depoliticization of the social relations of migration (Georgi 2007, pp. 72-73; de Jong 2016, p. 348). 
One of the key technologies for steering migration are the processes for the recruitment of nurses from abroad that were established through legal reforms. Of particular relevance to migration in nursing was the departure from a fixation on university degrees: $\S 6$, para. 2 of the Employment Regulation, which entered into force on 1 July 2013, enabled the immigration of individuals with vocational education and training credentials in occupations considered relevant to the labor market (Kolb 2014, p. 79). Technically, this key objective of migration management was implemented by determining (1) "recognized credentials" in (2) regulated vocational training occupations listed on the Federal Employment Agency's so-called "positive list (Positivliste)". It is compiled biannually on the basis of an analysis of shortages of skilled labor and lists occupations in which filling positions with applicants from abroad is considered "justifiable from a labor market and integration policy point of view" (Bundesagentur für Arbeit 2018b, p. 17). Steering migration via a list of occupations issued by the Federal Employment Agency attests to the high priority given to migration policy as an instrument to optimally coordinate labor supply and demand (Rand et al. 2019, p. 37). ${ }^{9}$

Another important technology in the care sector is the standardization of qualifications via the recognition of occupational credentials, which was regulated comprehensively in 2012 . This has resulted in regional differentiation: first come applications from long-time EU member states; second come applications from new EU member states (accession since 2004), in which case the occupational credential must have been acquired after accession to the EU; and third come applications from third countries (Sommer 2014, p. 78). What Sommer failed to take into account, and our study has been able to show, is that applications from third countries with placement agreements benefit enormously from such structured arrangements compared to other third countries, despite the formally required case-by-case review. A requirement for the recognition of credentials in nursing regardless of region of origin is, however, proof of knowledge of the German language. Depending on the state in question, this may be level B1 or B2 according to the Common European Framework of Reference for Languages or also certificates related to specific occupations such as B1 + Nursing.

Recently, the technologization of the steering of migration has also entailed digitization: the 2016 amendment of the EU Recognition Directive introduced the so-called European Professional Card. In combination with the Europe-wide Internal Market Information System (IMI), the card intends to expedite recognition procedures and thus the transfer of formal qualifications. This involves, for instance, digitizing and reviewing documents in advance so that, given sufficient language proficiency, recognition of credentials within Europe is granted at the click of a mouse (European Union 2019). In this way, digital communication technology, which was previously primarily discussed as a means of monitoring illegalized migration (Dijstelbloem and Broeders 2015; Sontowski 2017), has now also found its way into the management of labor migration.

The 2012 Recognition Act intended to facilitate recognition procedures, yet third country nationals are still subject to case-by-case reviews in the field of care, which poses a considerable obstacle. This illustrates the extent to which recognition authorities function as gatekeepers and, in the nursing field in particular, how the construction of differences in job tasks and training has an impact (Krawietz and Visel 2014). Research with case workers shows that, when assessing the equivalence of credentials, they looked for "substantial differences". The standard that they often applied in the process was that equivalence required "identical" content. Differences in training content were almost exclusively seen as deficiencies that needed to be offset and not as potential to be tapped (Sommer 2014, pp. 69-71). Resulting from the relevance of case worker decisions, as well as a differing legal basis, we can see that granting recognition is handled very differently depending on the certificates' region of origin (cf. Figure 3). For example, recognition procedures take considerably longer for third country diplomas and, in most cases, make recognition conditional on meeting certain compensation requirements.

9 In recent legislative procedures, the German parliament (Bundestag) resolved that, for the time being, the positive list would no longer be applied as an instrument of selection. The new law intends for immigration to be possible for all occupations in which professional or vocational credentials are recognized. 
Therefore, while our research shows how crucial recruitment programs like Triple Win are to streamline these processes with some success, the recognition of professional credentials remains the main obstacle to increased recruitment and migration of nurses from third countries. ${ }^{10}$ As the opposing trends in the number of applications from the EU versus the third states show, these stark differences in recognizing credentials swiftly and fully will only become more pertinent in the future.

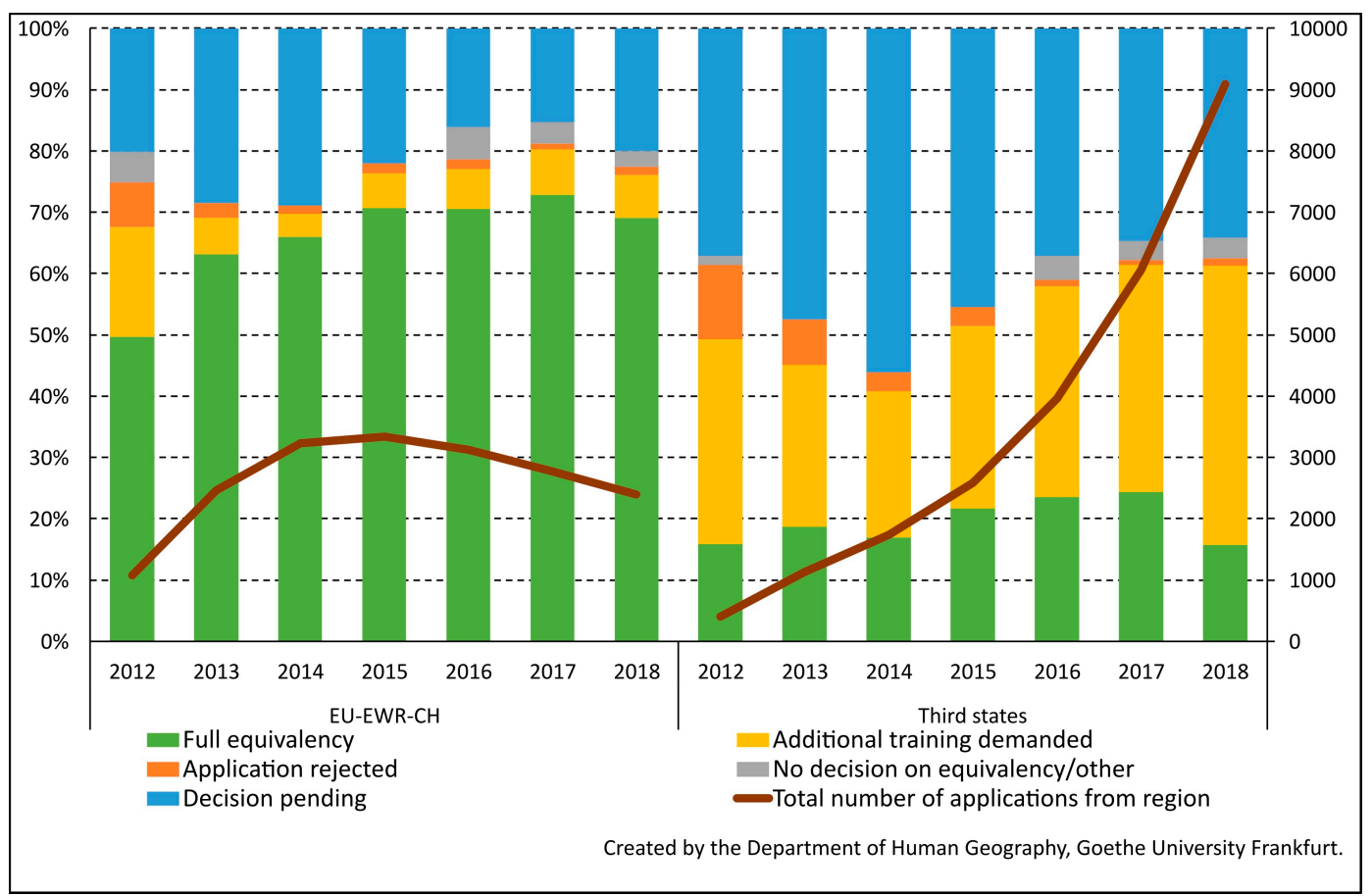

Figure 3. Decisions issued in new credential recognition procedures for registered nurses and total number of applications by region of origin, 2012-2018.

\section{Discussion and Outlook}

In this contribution, we used the example of recruiting nurses from abroad to demonstrate that analyses of migration management can be systematized along four dimensions: a first level of analysis shows that steered migration is widely considered a legitimate solution to the societal problem of the care crisis. The common reasoning underlying this perspective is exemplary for a demographization of social relations that involves obscuring the structural roots of the nursing shortage. Second, in the process of migration, categorizations of migrants come into play. Nurses are objectified in terms of language skills, as well as subjective requirements, and turned into the commodity of "nurse". Depending on the region of origin, this involves granting them different privileges, legal paths of access, and paths of migration. Third, their recruitment is increasingly organized in diversified actor networks in the context of changing statehood. In the care sector, this involves state initiatives as important initiators and loci of coordination that bring together additional private and intermediary actors, put the structures of recruitment in place, and set the process in motion. Fourth, it has proven fruitful to interpret the concrete instruments used in recruitment as technologies for steering migration. Apart from specific legal provisions and instruments such as the positive list, which make migration into regulated vocational training occupations possible in the first place, one of the main technologies is the standardization of nurses via recognition procedures.

The present contribution has shown that a migration policy oriented toward potential that takes the form of migration management finds paradigmatic expression in the recruitment of nurses as a strategy

10 On the problems inherent in the contemporary practice to require candidates to apply from abroad, see Best et al. (2019). 
to address the societal care crisis and the shortage of skilled personnel. These four distinct dimensions, which are of central importance to migration management, are intertwined via a shared rationality of economic utilitarianism (Rose and Miller 1992): the productive steering of migration and mobility in light of the increasing flexibilization of work and the economy. If we consider these developments from the viewpoint of critical migration research, we can confirm the thesis that migration management is dominated by a logistics mindset. The management of nurse recruitment analyzed here reflects the idea of being able to accomplish a sector-specific steering of migration just in time and to the point (Altenried et al. 2017, pp. 24-27).

We assume that the four dimensions of analysis outlined in this article can be transferred to other studies in the field of migration management as well. Such research could examine, for instance, recruitment projects in other shortage occupations or in other areas of migration management, such as programs for voluntary repatriation (Dünnwald 2010), or could probe in more detail single or several dimensions.

We predict for the future that recruitment will continue to increase, professionalize, and include market actors to a greater degree. The previously strictly regulated field of nurse recruitment will be subject to fewer and fewer legal restrictions. Moreover, those involved in recruitment are currently gaining experiential knowledge and are adapting the structures in public administration and private enterprises. In the event that the new immigration act (Bundesregierung der Bundesrepublik Deutschland 2019) is implemented as planned, this would make other third countries interesting targets for exclusively privately organized recruitment endeavors. In the near future, precarious recruitment could thus loom increasingly large, as standards (such as the Global Code of Practice in the recruitment of nurses) might be undermined if recruitment is guided by for-profit motives alone. The flipside of an increasingly positive connotation of migration in migration management discourse must also not be neglected: new programs for promoting 'desirable migration' go hand in hand with an increased exclusion and illegalization of 'undesirable' forms of migration, which are constructed as representing an economic burden or a politico-cultural threat (Menz 2011, p. 120; de Jong et al. 2017, p. 4). The relatively free movement of refugees through Europe in the summer of 2015 has additionally resulted in a shift in hegemonic discourses on migration and again unveiled racist and colonial continuities in the way we speak about 'migration' in general (Bhambra 2017; Jäger and Wamper 2017). To what extent these changes will also restructure the discourses on the migration of skilled labor remains to be seen.

Author Contributions: Conceptualization, J.K., R.P. and S.R.; Formal analysis, S.R.; Funding acquisition, R.P.; Methodology, R.P. and S.R.; Project administration, S.R.; Supervision, R.P.; Writing - original draft, J.K.; Writing review \& editing, J.K., R.P. and S.R. All authors have read and agreed to the published version of the manuscript.

Funding: This research received partial funding by the German Hans Böckler Foundation, grant number 2014-789-4.

Acknowledgments: The authors would like to thank Martina Blank and Mathias Rodatz for valuable comments on an earlier draft of this article, Annabell Baumgartner and Anna Lisa Jakobi for their support, and the anonymous reviewers for their thoughtful feedback.

Conflicts of Interest: The authors declare no conflict of interest. The funders had no role in the design of the study; in the collection, analyses, or interpretation of data; in the writing of the manuscript, or in the decision to publish the results.

\section{References}

Afentakis, Anja, and Tobias Maier. 2010. Projektionen des Personalbedarfs und-angebots in Pflegeberufen bis 2025. Available online: https://www.destatis.de/DE/Publikationen/WirtschaftStatistik/Gesundheitswesen/ ProjektionPersonalbedarf112010.pdf?_blob=publicationFile (accessed on 16 February 2019).

Altenried, Moritz, Manuela Bojadžijev, Leif Höfler, Sandro Mezzadra, and Mira Wallis. 2017. Politiken und Vermittlung mobiler Arbeit-ein Forschungsprojekt. In Logistische Grenzlandschaften: Das Regime mobiler Arbeit nach dem Sommer der Migration. Edited by Moritz Altenried, Manuela Bojadžijev, Leif Höfler, Sandro Mezzadra and Mira Wallis. Münster: UNRAST, pp. 15-141. 
Auth, Diana. 2017. Pflegearbeit in Zeiten der Ökonomisierung: Wandel von Care-Regimen in Großbritannien, Schweden und Deutschland. Münster: Westfälisches Dampfboot.

Balibar, Etienne. 2005. Difference, Otherness, Exclusion. Parallax 11: 19-34. [CrossRef]

Benner, Chris. 2003. Labour Flexibility and Regional Development: The Role of Labour Market Intermediaries. Regional Studies 37: 621-33. [CrossRef]

Best, Ulrich, Jessica Erbe, Nadja Schmitz, Stefan Arnold, Robert Koch, Sandra Mundt, and Friederike Rausch-Berhie. 2019. Berufliche Anerkennung im Einwanderungsprozess - Stand und Herausforderungen bei der Antragstellung aus dem Ausland: Ergebnisse des BIBB-Anerkennungsmonitorings (Vorabfassung). Available online: https://www.bibb.de/dokumente/pdf/2019_01_15_a3.3_fbi_best_berufliche_anerkennung einwanderungsprozess_1.pdf (accessed on 19 March 2019).

Bhambra, Gurminder K. 2017. The current crisis of Europe: Refugees, colonialism, and the limits of cosmopolitanism. European Law Journal 23: 395-405. [CrossRef]

Bild am Sonntag. 2018. Drei Minister leisten den Pflege-Schwur. June 30 . Available online: https:/www.bild.de/bild-plus/politik/inland/altenpflege/hier-versprechen-drei-minister-das-sieden-pflegenotstand-beenden-56170936 (accessed on 2 March 2019).

Bludau, Heidi. 2015. Creating a transnational labor chain between Eastern Europe and the Middle East. A case study in healthcare. InterDisciplines. Journal of History and Sociology 6: 95-120. [CrossRef]

Bonin, Holger, Grit Braeseke, and Angelika Ganserer. 2015. Internationale Fachkräfterekrutierung in der deutschen Pflegebranche: Chancen und Hemmnisse aus Sicht der Einrichtungen. Available online: https://www.bertelsmann-stiftung.de/fileadmin/files/Projekte/28_Einwanderung_und_Vielfalt/ Studie_IB_Internationale_Fachkraefterekrutierung_in_der_deutschen_Pflegebranche_2015.pdf (accessed on 25 February 2019).

Braeseke, Grit, Meiko Merda, Thomas K. Bauer, Sebastian Otten, Magdalena A. Stroka, and A. E. Talmann. 2013. Migration. Chancen für die Gewinnung von Fachkräften in der Pflegewirtschaft. Bundesgesundheitsblatt, Gesundheitsforschung, Gesundheitsschutz 56: 1119-26. [CrossRef]

Buckel, Sonja. 2012. Managing Migration - Eine intersektionale Kapitalismusanalyse am Beispiel der Europäischen Migrationspolitik. Berliner Journal für Soziologie 22: 79-100. [CrossRef]

Bundesagentur für Arbeit. 2018a. Arbeitsmarktsituation im Pflegebereich. Available online: https://statistik.arbeitsagentur.de/Statischer-Content/Arbeitsmarktberichte/Berufe/generischePublikationen/Altenpflege.pdf (accessed on 25 February 2019).

Bundesagentur für Arbeit. 2018b. Fachkräfteengpassanalyse Dezember 2018. Available online: https://statistik.arbeitsagentur.de/Statischer-Content/Arbeitsmarktberichte/FachkraeftebedarfStellen/Fachkraefte/BA-FK-Engpassanalyse.pdf (accessed on 25 February 2019).

Bundesministerium für Arbeit und Soziales. 2016. Sonderprogramm MobiPro-EU. Available online: https: //www.bmas.de/DE/Themen/Arbeitsmarkt/Modellprogramme/mobi-pro-eu.html (accessed on 16 February 2019).

Bundesministerium für Familie, Senioren, Frauen und Jugend. 2012. Ausbildungs- und Qualifizierungsoffensive Altenpflege 2012-2015. Available online: https://www.bmfsfj.de/blob/ 77250/7289d3d306c8d157d282ae5883c6fd64/vereinbarungstext-ausbildungs-und-qualifizierungsoffensiveapltenpflege-data.pdf (accessed on 25 February 2019).

Bundesministerium für Wirtschaft. 2012. Chancen zur Gewinnung von Fachkräften in der Pflegewirtschaft. Available online: https://www.bmwi.de/Redaktion/DE/Publikationen/Studien/chancen-zur-gewinnung-vonfachkraeften-in-der-pflegewirtschaft.pdf;jsessionid=92AF259DA9D2B6BE17748D2D662156E6?_blob= publicationFile\&v=10 (accessed on 3 March 2017).

Bundesregierung der Bundesrepublik Deutschland. 2018. Antwort der Bundesregierung auf die Kleine Anfrage der Abgeordneten Nicole Westig, Michael Theurer, Renata Alt, weiterer Abgeordneter und der Fraktion der FDP. Deutscher Bundestag Drucksache 19/5274. Available online: http://dipbt.bundestag.de/doc/btd/19/056/ 1905654.pdf (accessed on 7 March 2019).

Bundesregierung der Bundesrepublik Deutschland. 2019. Entwurf eines Fachkräfteeinwanderungsgesetzes, vom Bundestag beschlossen am 07.06.2019. Deutscher Bundestag Drucksache 19/8285. Available online: http://dip21.bundestag.de/dip21/btd/19/082/1908285.pdf (accessed on 21 July 2019).

Çalışkan, Koray, and Michel Callon. 2010. Economization, part 2: A research programme for the study of markets. Economy and Society 39: 1-32. [CrossRef] 
Chorus, Silke. 2013. Care-Ökonomie im Postfordismus: Perspektiven einer integralen Ökonomietheorie. Münster: Westfälisches Dampfboot.

de Jong, Sara. 2016. Converging logics? Managing migration and managing diversity. Journal of Ethnic and Migration Studies 42: 341-58. [CrossRef]

de Jong, Sara, Irene Messinge, Theresa Schütze, and Gerd Valchars. 2017. Migrationsmanagement: Praktiken, Intentionen, Interventionen (Editorial). Journal für Entwicklungspolitik 33: 4-21. [CrossRef]

Dijstelbloem, Huub, and Dennis Broeders. 2015. Border surveillance, mobility management and the shaping of non-publics in Europe. European Journal of Social Theory 18: 21-38. [CrossRef]

Dünnwald, Stephan. 2010. Politiken der "freiwilligen" Rückführung. In Grenzregime: Diskurse, Praktiken, Institutionen in Europa. Edited by Sabine Hess and Bernd Kasparek. Berlin and Hamburg: Assoziation A, pp. 179-99.

Düvell, Franck. 2002. Die Globalisierung des Migrationsregimes: Zur neuen Einwanderungspolitik in Europa. Berlin and Hamburg: Assoziation A.

Ehrentraut, Oliver, Tobias Hackmann, Lisa Krämer, and Sabrina Schmutz. 2017. Zukunft der Pflegepolitik-Perspektiven, Handlungsoptionen und Politikempfehlungen. Available online: https: //library.fes.de/pdf-files/wiso/12140.pdf (accessed on 4 March 2019).

Ette, Andreas, Stefan Rühl, and Lenore Sauer. 2012. Die Entwicklung der Zuwanderung hochqualifizierter Drittstaatsangehöriger nach Deutschland. Zeitschrift für Ausländerrecht und Ausländerpolitik 32: 14-21.

European Union. 2019. European Professional Card. Available online: https:/europa.eu/youreurope/citizens/ work/professional-qualifications/european-professional-card/index_en.htm (accessed on 10 March 2019).

Forschungsgruppe »Staatsprojekt Europa«, ed. 2014. Kämpfe um Migrationspolitik: Theorie, Methode und Analysen kritischer Europaforschung. Bielefeld: transcript.

Geiger, Martin, and Antoine Pécoud. 2010. 1 The Politics of International Migration Management. In The Politics of International Migration Management. Edited by Martin Geiger and Antoine Pécoud. Basingstoke: Palgrave Macmillan, pp. 1-20.

Georgi, Fabian. 2007. Migrationsmanagement in Europa: Eine kritische Studie am Beispiel des International Centre for Migration Policy Development (ICMPD). Saarbrücken: VDM Verlag Dr. Müller.

Georgi, Fabian, Nikolai Huke, and Jens Wissel. 2014. Fachkräftemangel, Lohndumping und Puzzle-Politik: Die europäische ,Blue Card’ als arbeitskraftpolitisches Projekt. In Kämpfe um Migrationspolitik: Theorie, Methode und Analysen kritischer Europaforschung. Edited by Forschungsgruppe »Staatsprojekt Europa«. Bielefeld: Transcript, pp. 209-25.

Hämel, Kerstin, and Doris Schaeffer. 2013. Who cares? Fachkräftemangel in der Pflege. Zeitschrift für Sozialreform 59: 413-31. [CrossRef]

Hedemann, Ulla, Lukas Worm, and Ingrid Artus. 2017. Mehr von uns ist besser für alle«: Dokumentation einer Veranstaltung zum Pflegestreik an der Charité. In Sorge-Kämpfe: Auseinandersetzungen um Arbeit in sozialen Dienstleistungen. Edited by Ingrid Artus, Peter Birke, Stefan Kerber-Clasen and Wolfgang Menz. Hamburg: VSA, pp. 116-29.

Hess, Sabine, Lisa-Marie Heimeshoff, Stefanie Kron, Helen Schwenken, and Miriam Trzeciak. 2014. Einleitung. In Grenzregime II: Migration-Kontrolle-Wissen. Transnationale Perspektiven. Edited by Lisa-Marie Heimeshoff, Sabine Hess, Stefanie Kron, Helen Schwenken and Miriam Trzeciak. Berlin and Hamburg: Assoziation A, pp. 9-39.

Hessisches Sozialministerium. 2013. Aus der Region Madrid in den Rheingau-Taunus: Spanische Fachkräfte unterstützen die Pflege. News release. Available online: https:/www.hessen.de/presse/pressemitteilung/ aus-der-region-madrid-den-rheingau-taunus-spanische-fachkraefte (accessed on 25 February 2019).

Jäger, Margarete, and Regina Wamper. 2017. Von der Willkommenskultur zur Notstandsstimmung: Der Fluchtdiskurs in deutschen Medien 2015 und 2016; Duisburger Institut für Sprach- und Sozialforschung. Available online: http://www.diss-duisburg.de/wp-content/uploads/2017/02/DISS-2017-Von-der-Willkommenskulturzur-Notstandsstimmung.pdf (accessed on 15 February 2020).

Kannankulam, John. 2014. Kräfteverhältnisse in der bundesdeutschen Migrationspolitik: Die Asyldebatte als Schlüsselereignis des schwerfälligen Wandels vom Gastarbeitsregime hin zu Managed Migration in der Bundesrepublik Deutschland. In Kämpfe um Migrationspolitik: Theorie, Methode und Analysen kritischer Europaforschung. Edited by Forschungsgruppe »Staatsprojekt Europa«. Bielefeld: Transcript, pp. 93-112. 
Kolb, Holger. 2014. Vom 'restriktiven Außenseiter' zum 'liberalen Musterland' - Der deutsche Politikwechsel in der Arbeitsmigrationspolitik. In Rapide Politikwechsel in der Bundesrepublik: Theoretischer Rahmen und empirische Befunde. Edited by Friedbert W. Rüb. Zeitschrift für Politik: Sonderband 6. Baden-Baden: Nomos, pp. 71-91.

Kordes, Jan. 2019. Anwerbeprogramme in der Pflege: Migrationspolitiken als räumliche Bearbeitungsweise der Krise sozialer Reproduktion. PROKLA 49: 551-67. [CrossRef]

Krawietz, Johanna, and Stefanie Visel. 2014. “Die examinierten Praktikanten”-Differenzkonstruktionen in der Anerkennung von ausländischen Pflegequalifikationen. In Prekarisierung transnationaler Carearbeit: Ambivalente Anerkennung. Edited by Johanna Krawietz and Stefanie Visel. Münster: Westfälisches Dampfboot, pp. 82-95.

Lagios, Thanasis, Vasia Lekka, and Grigoris Panoutsopoulos. 2018. Borders, Bodies and Narratives of Crisis in Europe. Cham: Springer International Publishing.

Meissner, Fran. 2018. Legal status diversity: Regulating to control and everyday contingencies. Journal of Ethnic and Migration Studies 44: 287-306. [CrossRef]

Menz, Georg. 2011. Neo-liberalism, Privatization and the Outsourcing of Migration Management: A Five-Country Comparison. Competition \& Change 15: 116-35. [CrossRef]

Moroşanu, Laura. 2016. Professional Bridges: Migrants' Ties with Natives and Occupational Advancement. Sociology 50: 349-65. [CrossRef]

Mourão Permoser, Julia. 2017. Redefining membership: Restrictive rights and categorisation in European Union migration policy. Journal of Ethnic and Migration Studies 43: 2536-55. [CrossRef]

Neues Deutschland. 2018. Politiker fordern Spurwechsel. August 17. Available online: https://www.neuesdeutschland.de/artikel/1097678.einwanderungsgesetz-politiker-fordern-spurwechsel.html (accessed on 2 March 2019).

Parusel, Bernd. 2010. Abschottungs- und Anwerbungsstrategien: EU-Institutionen und Arbeitsmigration. Wiesbaden: VS Verlag.

Peters, Verena, Esther Hofmann, Grit Braeseke, Katja Keller, Gertrud Stöcker, Manfred Schneider, Karmen Ozvatic, Angela Siebold, and Elisa Siebold. 2016. Handlungsempfehlungen für die Fachkräftegewinnung in der Altenpflege. Auszug aus der Studie "Begleitung des Pilotprojekts Fachkräftegewinnung für die Pflegewirtschaft". Available online: https://www.bmwi.de/Redaktion/DE/Publikationen/Studien/ pilotprojekt-fachkraeftegewinnung.pdf?__blob=publicationFile\&v=14 (accessed on 25 February 2019).

Prognos. 2012. Pflegelandschaft 2030: Eine Studie der Prognos AG im Auftrag der vbw-Vereinigung der Bayerischen Wirtschaft e.V. Available online: https:/www.prognos.com/fileadmin/pdf/ publikationsdatenbank/121000_Prognos_vbw_Pflegelandschaft_2030.pdf (accessed on 11 December 2017).

Pütz, Robert, and Mathias Rodatz. 2013. Kommunale Integrations- und Vielfaltskonzepte im Neoliberalismus: Zur strategischen Steuerung von Integration in deutschen Großstädten. Geographische Zeitschrift 101: 166-83.

Pütz, Robert, Maria Kontos, Christa Larsen, Sigrid Rand, and Minna-Kristiina Ruokonen-Engler, eds. 2019. Betriebliche Integration von Pflegefachkräften aus dem Ausland. Innenansichten zu Herausforderungen globalisierter Arbeitsmärkte. Available online: https://www.boeckler.de/pdf/p_study_hbs_416.pdf (accessed on 18September 2019).

Rand, Sigrid, Robert Pütz, and Christa Larsen. 2019. Die Herausbildung eines globalisierten Pflegearbeitsmarktes in Deutschland. In Betriebliche Integration von Pflegefachkräften aus dem Ausland. Innenansichten zu Herausforderungen globalisierter Arbeitsmärkte. Edited by Robert Pütz, Maria Kontos, Christa Larsen, Sigrid Rand and Minna-Kristiina Ruokonen-Engler. pp. 20-59. Available online: https://www.boeckler.de/ pdf/p_study_hbs_416.pdf (accessed on 18 September 2019).

Ratfisch, Philipp. 2015. Zwischen nützlichen und bedrohlichen Subjekten: Figuren der Migration im europäischen ,Migrationsmanagement' am Beispiel des Stockholmer Programms. movements. Journal für kritische Migrationsund Grenzregimeforschung 1: 1-26.

Rose, Nikolas, and Peter Miller. 1992. Political Power beyond the State: Problematics of Government. The British Journal of Sociology 43: 173-205. [CrossRef]

Rothgang, Heinz, Rolf Müller, Rainer Unger, Christian Weiß, and Annika Wolter. 2012. BARMER GEK Pflegereport 2012. Available online: https://www.barmer.de/blob/37026/cc127a3bf245e033dbdc9d20c938b07a/data/pdfpflegereport-2012.pdf (accessed on 25 February 2019). 
Schmitz, Nadja, and Stefan Winnige. 2019. Anerkennung ausländischer Berufsqualifikationen: Anträge aus dem Ausland im Spiegel der amtlichen Statistik: Ergebnisse des BIBB-Anerkennungsmonitorings (Vorabfassung). Available online: http://www.bibb.de/anerkennung-auslandsantraege (accessed on 7 March 2019).

Schultz, Susanne. 2016. Die zukünftige Nation. Demografisierung von Migrationspolitik und neue Konjunkturen des Rassismus. movements. Journal für kritische Migrations- und Grenzregimeforschung 2: 117-38.

Schwiter, Karin, Christian Berndt, and Linda Schilling. 2014. Ein sorgender Markt: Wie transnationale Vermittlungsagenturen für Seniorenbetreuung Im/mobilität, Ethnizität und Geschlecht in Wert setzen. Geographische Zeitschrift 102: 212-31.

Scott, Sam. 2017. Venues and Filters in Managed Migration Policy: The Case of the United Kingdom. International Migration Review 51: 375-415. [CrossRef]

Sommer, Ilka. 2014. Die Müh(l)en der staatlichen Anerkennung - Selektionsmechanismen der Umwandlung "ausländischer" in "deutsche" Pflegefachkräfte zwischen Berufsrecht und Anerkennungspraxis. In Prekarisierung transnationaler Carearbeit: Ambivalente Anerkennung. Edited by Johanna Krawietz and Stefanie Visel. Münster: Westfälisches Dampfboot, pp. 56-81.

Sontowski, Simon. 2017. Speed, timing and duration: Contested temporalities, techno-political controversies and the emergence of the EU's smart border. Journal of Ethnic and Migration Studies 27: 1-17. [CrossRef]

Szent-Ivanyi, Timot. 2018. Anwerbeprogramme für Pfleger aus dem Ausland laufen schleppend. Hannoversche Allgemeine. November 15. Available online: http://www.haz.de/Nachrichten/Politik/Deutschland-Welt/ Anwerbeprogramme-fuer-Pfleger-laufen-schleppend (accessed on 7 March 2019).

Tomei, Gabriele. 2016. Social Transformation, Subjectification, and Labour Migration: Theorizing the Heterogeneity of Migration Flows in the Current Italian Crisis. In An Anthology of Migration and Social Transformation. Edited by Anna Amelina, Kenneth Horvath and Bruno Meeus. Cham: Springer International Publishing, pp. 167-81.

WHO. 2006. Working Together for Health: The World Health Report 2006. Available online: http://www.who.int/ whr/2006/whr06_en.pdf (accessed on 5 October 2016).

Winker, Gabriele. 2015. Care Revolution: Schritte in eine solidarische Gesellschaft. Bielefeld: Transcript.

(C) 2020 by the authors. Licensee MDPI, Basel, Switzerland. This article is an open access article distributed under the terms and conditions of the Creative Commons Attribution (CC BY) license (http://creativecommons.org/licenses/by/4.0/). 